\title{
PENAMBAHAN KONSENTRASI EKSTRAK JAHE MERAH (Zingiber officenale Rocs) TERHADAP UJI ORGANOLEPTIK KELAPA DALAM
}

\author{
Siti Fatima ${ }^{1 *}$, Masriani Masriani ${ }^{2}$, Sovia Salsabila $^{3}$ \\ ${ }^{1,2,3}$ Program Studi Agroteknologi Sekolah Tinggi Ilmu Pertanian (STIP) Ypp Mujahidin, Tolitoli \\ *Email: sitifatima1414tima89@gmail.com.
}

Receive: 10 September 2019

Accepted: 7 Oktober 2019

\begin{abstract}
Addition of Concentration of Red Ginger Extract to Inner Elapa Oil Organoleptic Test (Cocos nucifera L), this study aims to determine the response to organoleptic tests in several samples of coconut oil added with red ginger extract. This study uses a Completely Randomized Design (CRD), which consists of 6 levels of treatment for each treatment combination repeated 3 times so that there are 18 samples. The results showed that the addition of $175 \mathrm{ml}$ ginger extract gave a good response to the organoleptic color, aroma and taste of deep coconut oil (VCO)
\end{abstract}

Key words : Organoleptic Test, Red Ginger

\section{ABSTRAK}

Penambahan Konsentrasi Ekstrak Jahe Merah Terhadap Uji Organoleptik minyak kelapa Dalam (Cocos nucifera L), penelitian ini bertujuan untuk mengetahui respons terhadap uji organoleptik pada beberapa sampel minyak kelapa yang di tambahakan dengan ekstrak jahe merah. Penelitian ini menggunakan Rancangan Acak Lengkap (RAL), yang terdiri dari 6 taraf perlakuan setiap kombinasi perlakuan di ulang sebanyak 3 kali sehingga terdapat 18 sampel. Hasil penelitian menunjukan bahwa penambahan esktrak jahe $175 \mathrm{ml}$ memberikan respons yang baik terhadap organoleptik warna,aroma dan cita rasa minyak kelapa dalam (VCO)

Kata Kunci : Uji Organoleptik, Jahe merah

\section{PENDAHULUAN}

Indonesia sebagai negara kepulauan terbesar memiliki kebun kelapa terluas dunia dengan luas areal sebesar 3.654.478 $\mathrm{Ha}$ atau setara dengan $30 \%$ dari total luas perkebunan kelapa dunia (Ditjenbun 2014). Indonesia juga merupakan negara penghasil kelapa terbesar di dunia yaitu, mencapai $34,9 \%$ dari total produksi, Fajrin 2012). Pohon kelapa merupakan salah satu komoditi perkebunan yang penting dalam pembangunan sub sektor perkebunan antara lain untuk memenuhi kebutuhan domestik, maupun sebagai komoditi ekspor penghasil devisa negara. Minyak kelapa murni merupakan produk olahan dari daging buah kelapa segar yang diolah tanpa proses pemanasan dan tidak melaui pemurnian dengan bahan kimia, sehingga komponenkomponen penting yang terkandung dalam minyak tetap dipertahankan (Tanasale 2013). Komponen utama dari VCO adalah asam- asam lemak jenuh dengan kandungan utamnya adalah asam laurat (48-58\%). Komponen lainnya adalah asam kaprat, asam kaprilat dan asam kaproat (Handayani 2010).

Tanaman jahe merupakan salah satu tanaman rempah-rempah yang tumbuh baik dan tersebar luas di wilayah Indonesia. Jahe (Zingiber officinale Rosc) termasuk komoditas yang diperdagangkan secara luas di dunia. Masyarakat Indonesia umumnya telah mengenal dan memanfaatkan jahe untuk berbagai kepentingan, misalnya sebagai campuran bahan makan dan minuman mulai dari tingkat tradisional sampai tingkat modern, maka perlu dibuat penganekaragaman produk olahannya. Jahe yang mengandung senyawa antioksidan digunakan sebagai bahan obat tradisional untuk penanggulangan maupun pengobatan beberapa penyakit, misalnya radang tenggorokan, demam, gangguan lambung, dan kurang darah. Jahe mengandung senyawa gingerol yang mempunyai aktivitas antioksidan yang tinggi. Menurut Rajalakshmi dan Narasimhan (Handayani 2010). Gingerol sebagai komponen bioaktif utama dalam jahe merupakan senyawa yang tahan panas, sehingga jahe dapat dikembangkan menjadi berbagai macam produk olahan. Bagai manakah perubahan warna, rasa dan aroma pada minyak kelapa dalam setelah di tambahkan ekstrak jahe merah, dengan menggunakan uji organoleptik, dan minuman mulai dari tingkat tradisional sampai tingkat modern. Adanya peningkatan kebutuhan masyarakat terhadap jahe, maka perlu dibuat penganekaragaman produk olahannya. Jahe yang mengandung senyawa antioksidan digunakan 
sebagai bahan obat tradisional untuk penanggulangan maupun pengobatan beberapa penyakit, misalnya radang tenggorokan, demam, gangguan lambung, dan kurang darah. Jahe mengandung senyawa gingerol yang mempunyai aktivitas antioksidan yang tinggi.

Tujuan dari penelitian ini adalah untuk mengetahui pengaruh penambahan ekstrak jahe merah,terhadap minyak kelapa dalam dengan metode pemanasan. Kegunaan penelitian ini yaitu sebagai informasi pada masyarakat dan produk ini juga diharapkan dapat digunakan sebagai alternatif produk pangan yang memiliki khasiat bagi kesehatan.

\section{Lokasi Penelitian}

\section{BAHAN DAN METODE}

Tempat pelaksanaan penelitian ini di Laboratorium Pertanian Sekolah Tinggi Ilmu Pertanian (STIP) Mujahidin Tolitoli, program studi Agroteknologi dan Penelitian ini dilaksanakan pada bulan September 2018.

\section{Bahan Dan Alat Penelitian}

Bahan utama yang digunakan dalam penelitian ini adalah jahe merah, kelapa. Alat yang digunakan pada penelitian yaitu gelas kimia, gelas ukur, timbangan digital, pisau, kertas lebel, camera, saringan yang berkain, parutan, kampak, panci, kompor hok, alat tulis menulis dan botol sampel.

Metode Penelitian

Penelitian ini disusun menggunakan Rancagan Acak Lengkap (RAL) yang terdiri dari 6 perlakuan konsentrasi jahe merah yaitu sebagai berikut:

$$
\begin{aligned}
& \text { S0 : Kontrol } \\
& \text { S1 : Konsentrasi } 1 \%(\mathrm{ml} / \mathrm{L}) \\
& \text { S2 : Konsentrasi } 2 \%(\mathrm{ml} / \mathrm{L}) \\
& \text { S3 : Konsentrasi } 3 \%(\mathrm{ml} / \mathrm{L}) \\
& \text { S4 : Konsentrasi } 4 \%(\mathrm{ml} / \mathrm{L}) \\
& \text { S5 : Konsentrasi } 5 \%(\mathrm{ml} / \mathrm{L})
\end{aligned}
$$

Sustrosupadi (2000) memberikan model

Rancangan Acak Lengkap (RAL)

Melalui model persamaan sebagai berikut:

$$
\begin{gathered}
\mathbf{Y i j}=\boldsymbol{\mu}+\mathbf{A} \mathbf{i}+\mathbf{\epsilon i j} \\
\mathrm{i}=1,2,3, \ldots \ldots \ldots \ldots, \mathrm{a} \quad \mathbf{j}=1,2,3 \ldots \ldots \ldots ., \mathrm{u}
\end{gathered}
$$

Yijk : Pengamatan Faktor Utama taraf ke-i , Ulangan ke-j dan

Faktor Tambahan taraf ke-k

$\mu \quad$ : Rataan Umum

Ai : Pengaruh Utama pada taraf ke-i

eij : Pengaruh Galat I pada Faktor Utama ke-i dan Ulangan ke-j

eijk : Pengaruh galat II pada Faktor Utama taraf ke-i, Ulangan

ke-j dan faktor tambanan pada taraf ke-k
Masing-masing perlakuan diulang sebanyak 3 kali sehingga terdapat 18 unit percobaan sampel VCO. Hasil penelitian dianalisa dengan sidik ragam dan apabila hasil menunjukkan ada pengaruh yang nyata diantara perlakuan maka akan dilanjutkan dengan Uji Duncan's Multiple Range Test (DMRT) .

\section{Pelaksanaan Penelitian}

Penyiapan Virgin coconut oil (VCO) Minyak Kelapa Dalam

Pertama menyediakan buah kelapa yang sudah tua sebanyak yang di butuhkan dalam perlakuan. kemudian buah kelapa tersebut di belah menggunakan kampak dan di bersihkan kulitnya lalu di ambil daging buah kelapa setelah itu buah kelapa di parut. Kelapa yang telah di parut di siram menggunakan air sedikit demi sedikit kemudian di peras dan di saring sehingga mengahsilkan santan yang kental. setelah santan sudah cukup kemudian dilakukan pemanasan dan memberikan ekstrak jahe merah.

Pembuatan Ekstrak Jahe Merah

Sebelum dilakukan pengambilan ekstrak jahe merah, terlebih dahulu di lakukan sortasi terhadap jahe merah dan kemudian dicuci dengan air bersih dan dibersihkan kulit luarnnya kemudian diparut, dan disring ambil ekstark jahennya sebanyak 1-5\% ml/l.

Pemberian Ekstrak Jahe Merah Terhadap Virgin coconu oil (VCO) Minyak Kelapa Dalam

Terlebih dahulu dilakukan pengukuran pada minyak kelapa sesuai perlakuan yang ada setelah itu ekstrak jahe merah di ukur sesuai dengan perlakuan yang ada, dan minyak kelapa yang sudah di ukur tersebut di campurkan dengan ekstrak jahe merah, kemudian dimasak menggunakan kompor 3 jam setelah itu di saring menggunakan saringan kain dan angin-angikan kemudian di isi ke dalam botol sampel, lalu dilakukan pengujian Orgonoleptik.

\section{Parameter Pengamatan}

Pengujian Orgonoleptik Aroma, Warna, Cita Rasa Terhadap Penambahan ekstrak Jahe Merah Pada Minyak Kelapa Dalam (VCO)

Pengujian terhadap sifat organoleptik aroma minyak kelapa dalam bertujuan untuk memperkirakan penerimaan konsumen terhadap produk, dengan uji orgonoleptik sebanyak 30 orang. Langkah pengujian organoleptik dilakukan melalui dua tahap. Tahap pertama yaitu penyamaan persepsi atribut sensori. Tahap kedua yaitu penilaian sensori aroma. Panelis menentukan intensitas parameter yang diuji dengan menggunakan garis skala yang telah disediakan pada kuisioner. 


\section{HASIL DAN PEMBAHASAN Penambahan Esktrak Jahe Merah Terhadap Warna Minyak VCO}

Hasil analisis duncan's menunjukan bahwa pengujian organoleptik terhadap warna minyak VCO memberi pengaruh yang sangat nyata pada taraf 5\% yang di tambahkan dengan ekstrak jahe merah, mempunyai tingkat kesukaan yang berbeda-beda terhadap warna minyak VCO yang di hasilkan. Berdasarkan data yang di peroleh nilai rata-rata tertinggi tingkat kesukaan terhadap warna dari minyak VCO yang di tambahkan dengan ekstrak jahe merah adalah (S5) 5,81 dapat dilihat pada gambar dibawah.



lihat pada setiap perlakuan pengamatan hasil uji organoleptik warna pada minyak VCO yang di tambahkan dengan konsentrasi ektrak jahe merah hasil tertinggi terdapat pada perlakuan (S5) menunjukan pengaruh nyata, dan pada perlakuan kontrol (S0) menunjukan tidak pengaruh nyata pada penambahan ekstrak jahe merah.

Berdasarkan hasil peneltian yang di lakukan bahwa penambahan ekstrak jahe merah pada minyak VCO sangat berpengaruh nyata, hasilnya sangat terlihat jelas bahwa di setiap perlakuan mempunyai warna yang berfariasi. di karenakan di setiap perlakuan penambahan ekstrak jahe merahnya yang berbeda. Semakin tinggi angka perlakuannya semakin tinggi juga ekstrak jahe yang di berikan serta proses pembuatan minyak dengan menggunakan suhu tinggi merupakan penyebab timbulnya warna kuning hal ini disebabkan karena karoten akan mengalami degradasi dalam suhu yang tinggi sehingga mempengaruhi warna minyak tersebut. Warna yang dikehendaki khusus untuk minyak VCO yaitu berwarna jernih dan tidak terdapat endapan dalam minyak tersebut.

Warna merupakan salah satu faktor fisual yang dapat menentukan penerimaan dari suatau produk, yang bernilai gizi, enak, dan teksturnya sangat baik dan kadang tidak di makan apa bila tidak memilki warna yang tidak menarik di pandang atau memberi kesan telah menyimpang dari warna yang seharusnya. Penerimaan suatu bahan pangan berbeda-beda tergantung dari faktor alam, geografis dan aspek sosial masyarakat penerima, (Winarno, 2008)

\section{Penambahan Ekstrak Jahe Merah Terhadap Aroma Minyak VCO}

Hasil analisis duncan's menunjukan bahwa pengujian oragnoleptik terhadap Aroma minyak VCO memberi pengaruh nyata pada taraf $5 \%$ yang di tambahkan dengan ekstrak jahe merah, dan penalis mempunyai tingkat kesukaan yang berbeda-beda terhadap Aroma minyak VCO yang di hasilkan. Berdasarkan data yang di peroleh nilai rata-rata tingkat kesukaan terhadap aroma dari minyak VCO yang di tambahkan ekstrak jahe merah adalah (S5) 5,70 dan dapat di lihat pada gambar di bawah.

Hasil uji Dunca's pada taraf 5\% dapat di lihat pada setiap perlakuan pengamatan hasil uji organoleptik aroma pada minyak VCO yang di tambahkan dengan konsentrasi ektrak jahe merah hasil tertinggi terdapat pada perlakuan (S5) menunjukan pengaruh nyata, dan pada perlakuan kontrol (S0) menunjukan tidak pengaruh nyata pada penambahan ekstrak jahe merah.

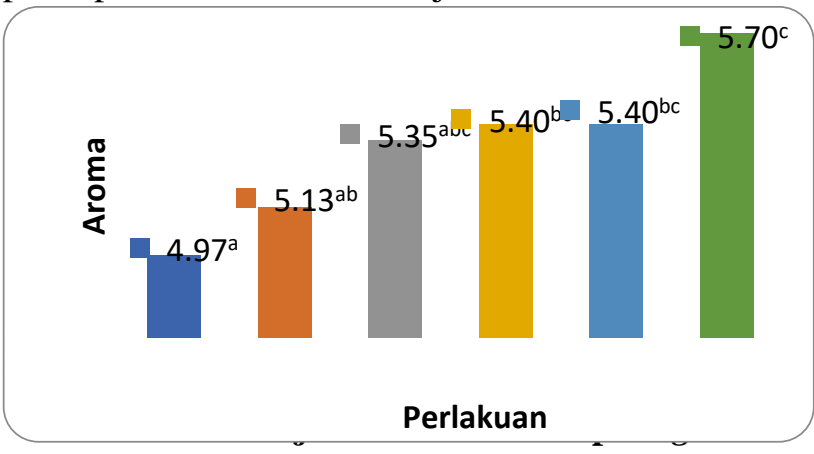

\section{Cococnut Oil (VCO)}

Berdasarkan hasil penelitian yang di lakukan bahwa penambhan ekstrak jahe merah pada minyak VCO berpengaruh nyata terhadap aroma minyak VCO. dan telah di lakukan uji organolepik terhadap aroma minyak VCO yang telah di tambahkan ekstrak jahe merah dengan proses menggoreng makanan, Hasilnya aroma dari jahe tersebut tercium agak pedas saat proses menggoreng makanan tersebut. Aroma merupakan salah satu parameter yang dapat dijadikan sebagai salah satu faktor untuk menentukan kualitas minyak. Uji aroma minyak dijadikan sebagai parameter karena minyak kelapa memiliki aroma yang khas dan berbeda dibandingkan dengan jenis minyak lainnya. Menurut Winarno (2008) kerusakan minyak kelapa (rancidity) disebabkan oleh oksidasi radikal asam tidak jenuh dalam lemak yang dipercepat dengan reaksi cahaya, panas, enzim dan yang lainnya. Bau tengik 
disebabkan oleh pembentukan senyawa-senyawa hasil pemecahan hidropiroksida.

\section{Penambahan Ekstrak Jahe Merah Terhadap Cita Rasa Minyak VCO}

Hasil analisis duncan's bahwa pengujian oragnoleptik terhadap cita rasa minyak VCO memberi pengaruh nyata pada taraf $5 \%$ yang di tambahkan dengan ekstrak jahe merah, dan penalis mempunyai tingkat kesukaan yang berbeda-beda terhadap cita rasaminyak VCO yang di hasilkan. Berdasarkan data yang di peroleh nilai rata-rata tertinggi tingkat kesukaan terhadap cita rasa dari minyak VCO yang di tambahkan ekstrak jahe merah adalah (S5) 5,76 dan dapat di lihat pada gambar di bawah ini.

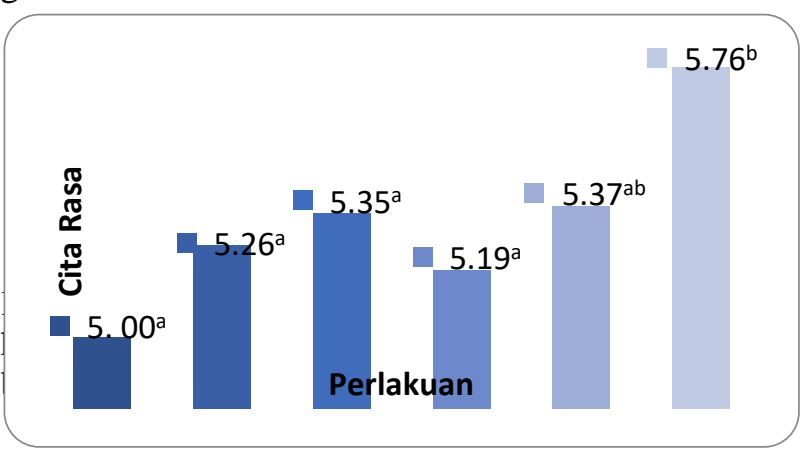

Cococnut Oil (VCO)

Hasil uji Duncan's pada taraf 5\% dapat di lihat pada setiap perlakuan pengamatan hasil uji organoleptik cita rasa pada minyak VCO yang di tambahkan dengan konsentrasi ektrak jahe merah hasil tertinggi terdapat pada perlakuan (S5) menunjukan pengaruh nyata, dan pada perlakuan kontrol (S0) menunjukan tidak pengaruh nyata pada penambahan ekstrak jahe merah.

Berdasarkan hasil penelitian yang di lakukan bahwa penambhan ekstrak jahe merah pada minyak VCO berpengaruh nyata. Dan hasilnya terlihat saat di adakan uji organoleptik, berdasarkan penilaian penalis saat mencicipi rasa dari minyak kelapa tersebut, rasanya agak pedas dan hangat di tenggorokan yang di sebabkan jahe mengandung gingerol, zingerone dan shogoal yang merupakan senyawa fenol dan bersifat antioksidan. Ketiga senyawa itulah yang menyebabkan rasa dominan pedas pada jahe sehingga dapat menghangatkan badan.

Rasa merupakan faktor yang sangat menentukan dalam keputusan akhir untuk menerima atau menolak suatu produk meskipun warna dan aroma minyak VCO sudah baik, tetapi apabila rasanya tidak enak maka produk tersebut akan di tolak. Menurut Winarno (2008) rasa di pengaruhi oleh beberapa faktor, yaitu senyawa kimia, suhu, konsentrasi dan interaksi dengan komponen rasa yang yang lain. Rasa pada makanan atau minuman merupakan faktor kedua yang mempengaruhi cita rasa setelah penampilan makanan atau minuman itu sendri. Rasa merupakan tanggapan atas adanya rangasangan kimiawi yang sampai di indra pengecap lidah, hususnya jenis dasar manis, asin, asam dan pahit (Meilgaard et al 2000).

\section{KESIMPULAN}

Dari hasil penelitian pengaruh penambahan konsentrasi ekstrah jahe merah terhadap uji organoleptik minyak kelapa dalam (VCO) di peroleh bahwa penambahan ekstrak jahe merah sebanyak $175 \mathrm{ml} / \mathrm{l}$ sangat pengaruhnyata terhdap warna, aroma, dan cita rasa yang di hasilkan.

\section{UCAPAN TERIMA KASIH}

Dengan memanjatkan kehadirat Allah S.W.T, Atas anugrah yang telah di berikan kepada penulis, sehingg penulis dapat menyelesaikan penelitian ini. "Pengaruh Penambahan Konsentrasi Ekstrak Jahe Merah (Zingiber Officinale Rosc) Terhadap Uji Organoleptik Minyak Kelapa Dalam". Dengan segala kerendehan hati dan rasa sujudku, penulis menyampaikan penghargaan dan ucapan terimakasih yang sebesar-besarnya kepada kedua orang tuaku tercinta dan tersayang, Ayahanda Ramba dan ibunda Sumiati, atas limpahan kasih sayang dan do'a pengertian serta pengorbanan yang begitu tulus untuk penulis, sehingga penulis dapat menyelesaikan penelitian dan penulisan artikel ini.

Selanjutnya penulis tak lupa pula mengucapkan terimakasih yang setinggi-tingginya kepada :

1. Bapak Syarifuddin Ende, SP. M.Si, selaku Ketua Sekolah Tinggi Ilmu Pertanian (STIP) YPPMujahidin Tolitoli, yang telah memberikan kesempatan kepada penulis untuk melaksanakan penelitian.

2. Ibu Yulianti Rasud, S.Pd, M.Si selaku Ketua Program Studi Agroteknologi pada Sekolah Tinggi Ilmu Pertanian (STIP) YPP -Mujahidin Tolitoli.

\section{DAFTAR PUSTAKA}

Ditjenbun. Direktorat Jendral Perkebunan. 2014. Statistik Perkebunan Indonesia Komoditas Kopi 20132015. Ditjenbun. Jakarta.

Fajrin E, 2012. Penggunaan Enzim Bromelin pada Pembuatan Minyak Kelapa (Cocos nucifera) Secara Enzimatis. Makasar: Universitas Hasanuddin

Handayani NRR, 2010. Kualitas Berbagai Produk VCO (Virgin Coconut Oil) Ditinjau dari Kadar Protein dan Logam. Skripsi. Tidak Dipublikasikan. Yogyakarta: Universitas Islam Negeri Sunan Kalijaga

Hapsoh dan Hasanah, Y., 2008. Budidaya Tanaman Obat dan Rempah. USU Press. Medan 
Momuat, L. I., Meiske, S. S., Ni, P. P. Pengaruh VCO Mengandung Ekstrak Wortel Terhadap Peroksida Lipid Plasma. Jurnal Ilmiah Sains. 11: 296 - 301

Meilgaard, M., G. V. Civille and B. T. Carr. 1999. Sensory Evalustion Tecniques. CRC Press. New York Wikepedia. "Carboxymethil Celullose". Dalam http://wiskipedia. Encyclopedia.com. diakses 10 Juli 2012.

Tanasale MLP. 2013. Aplikasi ragi tape terhadap rendemen dan mutu VCO. Jurnal Ekosains 2: 4752. Time of Thermal Processing on Ginger (Zingiber offinacinale Roscoe) Rhizome Antioxidant Coumpounds and Its Quality. International Food Research Journal. Brawijaya University, Malang

Winarno, F.G. 2008. Kimia Pangan dan Gizi. Bogor : MBrio Perss. 
